\title{
Diversity of soil macroarthropods in shifting cultivation and forest ecosystem of Mizoram, Northeast India
}

Betsy Zodinpuii

Department of Zoology, Pachhunga University College, Mizoram University, Aizawl- 796001 (Mizoram), India

Lalnuntluanga

Department of Environmental Science, Mizoram University, Tanhril, Aizawl- 796005 (Mizoram), India

H. Lalthanzara*

Department of Zoology, Pachhunga University College, Mizoram University, Aizawl- 796001 (Mizoram), India

*Corresponding author. E-mail: hzara.puc@gmail.com

\begin{abstract}
Soil organisms are an integral part of agricultural ecosystems and are essential for the maintenance of healthy productive soils. Little is known about soil arthropods assemblages in shifting cultivation system. Therefore, we compared the diversity of soil macroarthropods in shifting cultivation (EXPTL) system and its adjacent natural forest (CTRL) ecosystem in Mizoram, northeast India and assessed the impact of shifting cultivation on the diversity. The study was conducted from 2013 to 2015 , and the period was divided as pre -cultivation, cultivation and post-cultivation phases. Traditional shifting cultivation was practised in EXPTL site in the year 2014. Sampling was done by handpicking and digging from a quadrat $(25 \times 25 \times 30 \mathrm{~cm})$ located at least $10 \mathrm{~m}$ apart at monthly intervals. Specimens were preserved in $4 \%$ formalin and were identified up to the lowest possible taxa. A total of 97 taxa of arthropods belonging to five classes were recorded. 88 taxa and 48 taxa were recorded in CTRL and EXPTL respectively. Order-wise Shannon diversity index was significantly higher $(p<.001)$ in CTRL as compared to EXPTL site. There were significant differences in both cultivation $(p<.001)$ and post-cultivation $(p<.001)$ phases between CTRL and EXPTL sites. There was a significant effect of shifting cultivation on the diversity of soil macroarthropods at the $p<.05$ level for the three cultivation phases in EXPTL site. Therefore, it was concluded that shifting cultivation system negatively affected soil macroarthropod diversity at least for a short duration. This study provided the first baseline data of soil macroarthropod diversity and its interaction with land-use system from Mizoram, northeast India.
\end{abstract}

Keywords: Macroarthropod, Mizoram, Natural forest, Shifting cultivation, Soil

\section{Article Info}

https://doi.org/

10.31018/jans.v11i3.2122

Received: June 1, 2019

Revised: July 10, 2019

Accepted: August 17, 2019

\section{How to Cite}

Zodinpuii, B. et al. (2019). Diversity of soil macroarthropods in shifting cultivation and forest ecosystem of Mizoram, Northeast India. Journal of Applied and Natural Science, 11 (3): 601- 611 https:// doi.org/10.31018/ jans.v11i3.2122

\section{INTRODUCTION}

Soil is the most diverse and is probably one of the most species-rich habitats of the terrestrial ecosystem (Decaëns et al., 2006). Soil organisms are an integral part of agricultural ecosystems and their presence is essential for the maintenance of healthy productive soils. Soil macroarthropods are those soil organisms that are large enough to be sampled individually (Callaham et al., 2012). Although several groups of soil macroarthropods are considered as pests (Jackson and Klein, 2006; Doğramaci and Tingey, 2009), they are also known to positively influenced ecosystem functions by causing important modifications in the soil environment (Lavelle, 1997; Wolters, 2000). Despite their important roles and functions in the ecosystem, soil communities are still poorly known (Hunter, 2001). The study of soil animal has been a neglected field for a long time particularly in India but has gained popularity recently.

Soil macroarthropods play an important role in various ecosystem functions. Ants, termites, millipedes, centipedes, woodlice and beetles have a vital role in macromixing, soil aggregate formation, mineralization of inorganic nutrients through activation of microflora (Ruiz et al., 2008). They also take part in formation of macropores which are important for soil aeration and water flux (Edwards and Bohlen, 1996). The crucial roles played by the soil arthropods in soil ecosystem make them a very important part of all ecosystems, including agroecosystems. The reduction in the diversity of soil arthropod is likely to cause improper functioning of the ecosystem. In addition, the potential use of soil arthropods as biological indicators of habitat destruction and land use has been gaining 
popularity (Andersen and Majer, 2004; Nakamura et al., 2007). Previous study has shown that the undisturbed forest provides the ideal environment for the establishment of ecosystem engineers (Brown et al., 2001).

Considerable amounts of literatures are available from different parts of the world, but majority of soil faunal studies are done in temperate habitats (Okwakol and Sekamatte, 2007).

The earliest taxonomic records of soil fauna from the Indian sub-continent dates back to the $19^{\text {th }}$ century; Pocock (1892) studied the grounddwelling myriapods of the then Ceylon (Sri Lanka) and Southern India. Commendable work was done by Bingham (1903) on ground dwelling ants and Imms (1912) on collembolans. Review on soil fauna was given thoroughly by Singh (1978). Rossi and Blanchart (2005) studied seasonal and land use induced variations of soil macrofauna composition in the Western Ghats, southern India.

Many authors have shown soil arthropod population structure in different cultivated lands of northeast India (Reddy and Alfred, 1978; Vatsauliya and Alfred, 1980; Vatsauliya, 1981; Darlong and Alfred, 1982; Hattar and Alfred, 1984; Paul and Alfred, 1995; Alfred et al., 1991; Hattar et al., 1992, 1998, 2008). However, there is no information on this aspect from Mizoram. Traditional shifting cultivation is believed to have an adverse effect on soil arthropod community. Although data exist on various aspects of soil macroarthropods, information on their diversity and the effects of shifting cultivation system on macroarthropods is scarce. Moreover, very little is known about soil arthropods assemblages in shifting cultivation system. Keeping in mind their crucial roles as soil ecosystem engineers, the scarcity of systematic information on this aspect and to find an answer to the hypothesized concept, the experiment was designed to study the diversity of soil macroarthropods in shifting cultivation system and natural forest ecosystem and to find out the impact of shifting cultivation on the diversity of soil macroarthropods in in Mizoram, northeast India.

\section{MATERIALS AND METHODS}

Study area: Mizoram is located in northeast India, between $21^{\circ} 56^{\prime} \mathrm{N}$ and $24^{\circ} 31^{\prime} \mathrm{N}$ latitude, 92 $16^{\prime} \mathrm{E}$ and $93^{\circ} 26^{\prime} \mathrm{E}$ longitude. It borders with Bangladesh in the west and Myanmar in the east and south. In the north, it shares a border with three Indian states viz. Tripura in the north-west, Assam in north and Manipur in the northeast (Fig. 1). The state is hilly, covered with tropical and subtropical semi-evergreen forests, and is a part of IndoMyanmar Biodiversity Hotspot hence its location is biologically significant. The average temperature varies between $11{ }^{\circ} \mathrm{C}$ and $21^{\circ} \mathrm{C}$ in winter and climbs up to $20^{\circ} \mathrm{C}$ and $33^{\circ} \mathrm{C}$ in summer months. The soil of Mizoram is slightly acidic; $\mathrm{pH}$ generally ranges from $4.5-7$. It receives an annual rainfall of about $2500 \mathrm{~mm}$.

Shifting cultivation is the ultimate source of nourishment and subsistence for more than half of all household in Mizoram. It involves slashing of vegetation in December or early January after which the slashed vegetation is left to dry and the dried vegetations are burnt in mid-March. Sowing of seeds is generally done in April/May and the first weeding is usually carried out in May/June. Multiple cropping system is typically employed with different kinds of crops such as bitter gourd, bitter tomato, brinjal, cassava, chilly, cucumber, ginger, honeydew melon, lady's finger, maize, peas, pumpkin, sesame, snake gourd, solanum, sorghum, sorrel, soybean, sweet potato, taro, watermelon and other vegetables for leaves and fruits with rice (Oryza sativa L.) as the main crop. Weeding using a hand hoe is usually carried out three times a year, where weeds are dragged out along with roots while upper fertile soil is semitilled. This traditional shifting cultivation was performed for one year, after which the land was left for regeneration (fallow) in the subsequent years.

Experimental design: The study was carried out at an experimental plot of natural tree forest at Khawrihnim village (233' $58^{\prime \prime} \mathrm{N}$ and $\left.92^{\circ} 38^{\prime} 04^{\prime \prime} \mathrm{E}\right)$, Mamit district, Mizoram at an altitude of about 950 $\mathrm{m}$ above sea level. The landscape is steep with a slope ranging from $45 \%$ to $75 \%$. The plot was demarcated into control (CTRL, natural forest) and experimental (EXPTL, cultivation site) sites with an area of one acre each. The study period was divided in to three phases, viz. pre- cultivation phase (2013), cultivation phase (2014) and post cultivation phase (2015). Traditional shifting cultivation was practiced in EXPTL site in the year 2014.

Soil arthropods sampling and identification: Soil macroarthropod samples were collected from CTRL and EXPTL sites by hand picking and digging from a quadrat $(25 \times 25 \times 30 \mathrm{~cm})$ located at least $10 \mathrm{~m}$ apart at monthly intervals (Anderson and Ingram, 1993; Swift and Bignell, 2001) during January 2013 to October 2015. Large sized fauna like centipede and millipede were hand-sorted at the site, whereas a lump of soil block was taken to laboratory and small sized fauna were thoroughly extracted by hand sorting method (Dash and $\mathrm{Pa}$ tra, 1977; Dash and Senapati, 1980). Specimens were preserved in $4 \%$ formalin. Morphological based identification of arthropods using Motic Stereo Zoom Microscope (SMZ-160) was done up to the lowest possible taxa following Castner (2000), Arnett and Jacques (1981), Gibb et al. (2006) and also other literatures including online literatures and pictorial guides. The identified specimens were deposited to Pachhunga University College Zoological Museum, Mizoram, India.

Statistical analysis: Soil macroarthropods diver- 
sity indices were calculated by using Palaeontological Statististics (PAST) following Hammer et al. (2001). t-test and ANOVA were calculated by SPSS software version 16.

\section{RESULTS}

This study recorded 97 species of arthropods belonging to five classes which are presented in tables $1-5$. Of these, 88 taxa occurred in CTRL site whereas only 48 taxa were recorded from EXPTL site. Shannon diversity index at the level of Order was significantly higher $(t=3.6661, \mathrm{p}$ $<.001)$ in CTRL $(\overline{\mathrm{H}}=1.338)$ as compared to EXPTL $(\bar{H}=1.164)$ site. Larval forms were excluded from this study due to problems in identification.

Class Arachnida: Arachnids are a class of jointed eight-legged invertebrate animals. A total of 14 species from four orders of arachnids were identified up to family level from the study sites during the course of study (Table 1). Out of the total 14 species, eight species were spiders, belonging to order Araneae, which were identified up to family level including one unidentified family. In addition, four species of Harvestman/ Daddy long legs under the order Opiliones and one species each from order Scorpiones and order Pseudoscorpionida were also identified. A total of eight species were found in EXPTL whereas all the 14 species were recorded from CTRL site. The order Araneae has a statistically significant $(t=2.2722, p=$ $0.0254)$ higher species diversity in CTRL $(\bar{H}=$ 1.792) as compared to EXPTL $(\overline{\mathrm{H}}=1.468)$ site (Table 6).

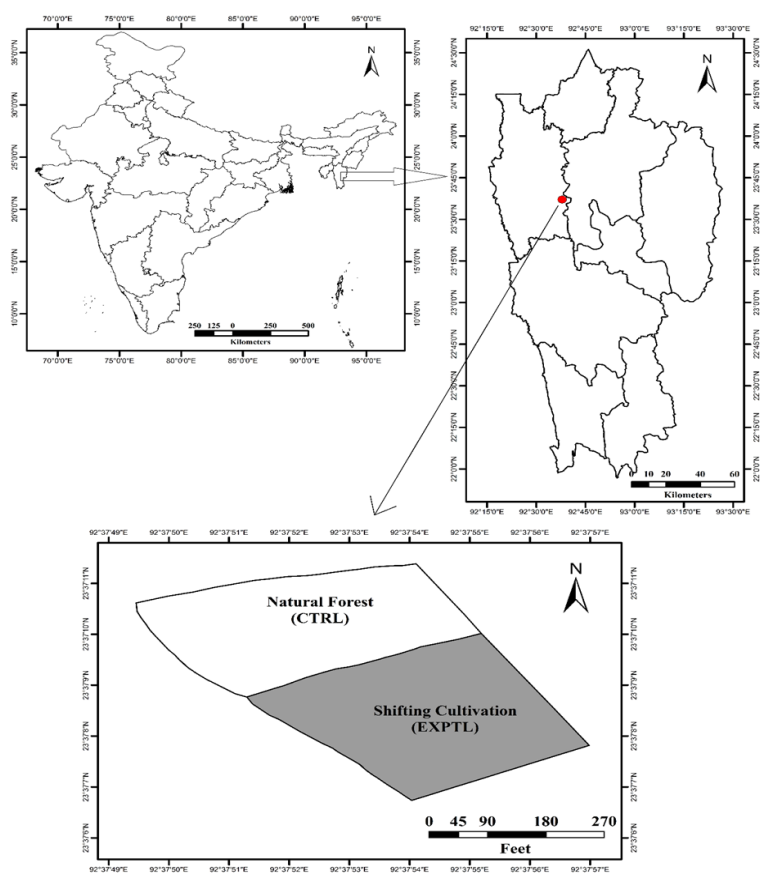

Fig. 1. Location of study site in Mizoram, northeast India.
Class Crustacea: Five species of crustaceans under two orders Isopoda and Amphipoda were collected from the study sites (Table 2). All the five species were found in CTRL whereas only three species were recorded from EXPTL site. Shannon diversity index of Isopoda in CTRL site $(\bar{H}=1.208)$ was significantly higher $(t=2.8524, p=0.008)$ than that of EXPTL site $(\overline{\mathrm{H}}=0.682)$ (Table 6$)$.

Class Insecta: Class Insecta constitutes the most abundant class in terms of species composition; it constitutes 67 species out of 97 species collected from this study. The recorded 67 species belong to ten orders and are presented in Table 3. Order Diplura, Collembola and Homoptera were represented by only one species each.

Order Orthoptera was represented by three species under three families. Also, Order Isoptera was represented by three species belonging to family Termitidae. Order Dermaptera was represented by four species under four families including one unidentified species under family Chelisochidae. Order Blattaria was represented by five species under three families. Order Hemiptera was represented by seven species under seven families. Order Coleoptera was represented by 32 species belonging to ten families and constituted the largest order in terms of species composition under the class Insecta. Order Hymenoptera was represented by nine species under family Formicidae and one unidentified species belonging to family Mutillidae.

Out of the total 67 soil insect species, 59 species were recorded in CTRL whereas only 39 species were recorded from EXPTL site. The Shannon diversity index of various soil arthropod orders is presented in table 6 . The diversity indices of Blattaria, Isoptera, Orthoptera, Hemiptera, Coleoptera and Hymenoptera were significantly $(p<.05)$ higher in CTRL as compared to EXPTL site.

Class Chilopoda: Chilopods are elongated metameric creatures with one pair of legs per body segment represented by Centipede. Five species of centipedes from two orders and three families were collected from the study sites (Table 4). The

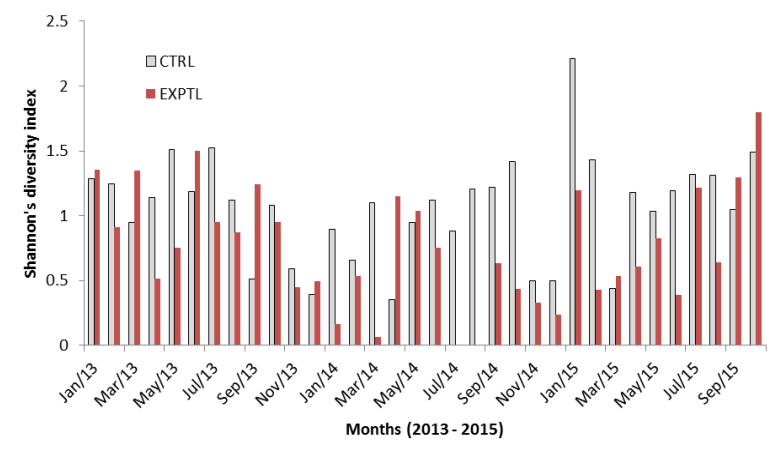

Fig. 2. Monthly variations in diversity ( $\bar{H})$ of soil macroarthropods in CTRL and EXPTL sites in Mizoram, northeast India. 
Zodinpuii, B. et al. / J. Appl. \& Nat. Sci. 11(3): 601- 611 (2019)

Table 1. Species composition of soil arthropods (Arachnids) in Mizoram, northeast India

\begin{tabular}{llllc}
\hline Class/ Order & Family & Taxa & \multicolumn{2}{c}{ Occurrence } \\
\cline { 3 - 5 } Arachnida araneae & Ctenidae & Unidentified & CTRL & EXPTL \\
& Lycosidae & Unidentified & + & + \\
& Cybaeidae & Unidentified & + & - \\
& Theraphosidae & Unidentified & + & - \\
& Clubionidae & Unidentified & + & + \\
& Sparassidae & Unidentified & + & + \\
& Salticidae & Unidentified & + & + \\
& Unidentified & Unidentified & + & - \\
Opiliones & Pettalidae & Pettalus thwaitesi, Sharma et al. & + & + \\
& Sclerosomatidae & Leiobunum sp.1 & + & - \\
& & Leiobunum sp.2 & + & + \\
Scorpiones & & Gagrella sp. & + \\
Pseudoscorpionida & Scorpionidae & Unidentified & - \\
\hline
\end{tabular}

Table 2. Species composition of soil arthropods (Crustaceans) in Mizoram, northeast India.

\begin{tabular}{llllc}
\hline \multirow{2}{*}{ Class/ Order } & Family & Taxa & \multicolumn{2}{c}{ Occurrence } \\
\cline { 3 - 5 } & Armadillidiidae & Armadillidium sp. & $\mathbf{+}$ & EXPTL \\
\hline Crustacea Isopoda & Philosicidae & Philoscia sp. & + & $\mathbf{+}$ \\
& Porcellionidae & Porcellio sp. & + & - \\
Amphipoda & Oniscidae & Oniscus sp. & + & $\mathbf{+}$ \\
\hline
\end{tabular}

$+=$ present, $-=$ absent

only species representing order Scolopendromorpha was collected from the EXPTL site during November 2013. Majority of the collected centipedes from both CTRL and EXPTL sites were members of order Geophilomorpha. All five species were recorded from EXPTL whereas CTRL harbours four species only. Shannon diversity index value for CTRL $(\bar{H}=1.360)$ was though slightly lower than EXPTL $(\overline{\mathrm{H}}=1.460)$ site (Table $6)$.

Class Diplopoda: Diplopods are a group of arthropods that are characterized by having two pairs of jointed legs on most body segments represented by a millipede. Six species of millipedes belonging to three orders and five families were identified (Table 5). Order Polydesmida was represented by three species belonging to two families and Order Spirostreptida was represented by two species under two families while Order Sphaerotheriida was represented by only one species. Only three species were recorded from EXPTL site whereas all the six species were found in CTRL site. The Shannon diversity index of CTRL $(\bar{H}=1.552)$ was significantly higher $(t=$ $5.499, p<.001)$ than that of EXPTL $(\overline{\mathrm{H}}=0.885)$ site (Table 6).

Effect of shifting cultivation on soil macroarthropod diversity: Three years data on monthly variations in the diversity of soil arthropods in CTRL and EXPTL sites is presented in Fig. 2 and indices calculated to provide information on soil macroarthropod diversity, richness and others are presented in table 7 . During the pre-cultivation phase, i.e. before shifting cultivation was employed in EXPTL site Shannon's diversity index ( $\overline{\mathrm{H}}$ ) value was 1.364 . In the year 2014, traditional shifting cultivation was employed in EXPTL site during which Shannon's diversity index $(\bar{H})$ value was reduced to 0.667 . During post-cultivation phase, EXPTL site was left fallow and throughout the year 2015 Shannon's diversity index $(\overline{\mathrm{H}})$ value was increased to 1.148 (Table 7).

Independent samples t-test was conducted to determine if there were significant variations in the diversity of soil macro arthropods during the three cultivation phases in CTRL and EXPTL sites. There were no significant differences $(p>05)$ in diversity between CTRL and EXPTL sites in precultivation phase. However, there was significant differences in diversity between CTRL and EXPTL sites in both cultivation $(t=4.7522, p<.001)$ and post-cultivation ( $t=3.8488, p<.001)$ phases. Thus, there was a sharp decrease in diversity during cultivation and a gradual restoration of population diversity in the next year (post-cultivation).

One-way ANOVA was conducted to determine if there were significant inter-annual variation (cultivation phases in EXPTL site) in both CTRL and EXPTL sites. While there was no significant changes in the diversity of soil macroarthropods in CTRL site at the $p<.05$ level for the three cultivation phases $\left[F_{(2,31)}=2.525, p=.096\right]$, there was significant effect of shifting cultivation on the diver- 
Zodinpuii, B. et al. / J. Appl. \& Nat. Sci. 11(3): 601- 611 (2019)

Table 3. Species composition of soil arthropods (Insects) in Mizoram, northeast India.

\begin{tabular}{|c|c|c|c|c|}
\hline \multirow{2}{*}{ Class/ Order } & \multirow{2}{*}{ Family } & \multirow{2}{*}{ Taxa } & \multicolumn{2}{|c|}{ Occurrence } \\
\hline & & & CTRL & EXPTL \\
\hline Insecta Diplura & Japygidae & Metajapyx sp. & + & + \\
\hline \multirow{6}{*}{$\begin{array}{l}\text { Collembola } \\
\text { Blattaria }\end{array}$} & Entomobryidae & Unidentified & - & + \\
\hline & Blattidae & Blatta sp. & + & + \\
\hline & Ectobiidae & Parcoblatta sp. & + & + \\
\hline & & Blatella sp. & + & - \\
\hline & Blaberidae & Pycnoscelus surinamensis, Linnaeus & + & - \\
\hline & & Epilampra sp. & + & - \\
\hline \multirow[t]{3}{*}{ Isoptera } & Termitidae & Odontotermes sp.1 & + & + \\
\hline & & Odontotermes sp.2 & + & - \\
\hline & & Odontotermes sp.3 & + & - \\
\hline \multirow{4}{*}{ Dermaptera } & Forficulidae & Forficula auricularia, Linnaeus & + & + \\
\hline & Labiduridae & Labidura sp. & + & - \\
\hline & Anisolabididae & Euborellia annulipes, Lucas & - & + \\
\hline & Chelisochidae & Unidentified & + & - \\
\hline \multirow[t]{3}{*}{ Orthoptera } & Gryllacrididae & Unidentified & + & - \\
\hline & Tetrigidae & Unidentified & + & + \\
\hline & Gryllotalpidae & Unidentified & + & - \\
\hline \multirow{7}{*}{ Hemiptera } & Pyrrhocoridae & Dysdercus sp. & - & + \\
\hline & Reduvidae & Unidentified & - & + \\
\hline & Miridae & Unidentified & + & - \\
\hline & Pentatomidae & Unidentified & - & + \\
\hline & Scutelleridae & Unidentified & - & + \\
\hline & Cydnidae & Unidentified & + & - \\
\hline & Coreidae & Unidentified & - & + \\
\hline Homoptera & Cicadidae & Unidentified & + & - \\
\hline \multirow[t]{32}{*}{ Coleoptera } & Crabidae & Platynus sp. & + & + \\
\hline & & Badister sp. & + & - \\
\hline & & Anisodactylus sp. & + & - \\
\hline & & Notiobia sp. & + & + \\
\hline & & Harpalus sp. & + & + \\
\hline & Histeridae & Saprinus lugens, Erichson & + & + \\
\hline & & Saprinus oregonensis, Le Conte & + & + \\
\hline & Staphylinidae & Coproporus ventriculus, Say & + & + \\
\hline & & Scaphisoma rubens, Casey & + & - \\
\hline & & Borolinus curticollis, Bernhauer & + & + \\
\hline & & Philonthus indubius, Luze & + & + \\
\hline & & Oropus striatus, Le Conte & + & - \\
\hline & & Pselaphus sp. & + & + \\
\hline & & Pselaphus heisei, Herbst & + & + \\
\hline & & Siagonium sp. & + & + \\
\hline & & Platydracus sp. & + & + \\
\hline & Dermestidae & Diplocoelus sp. & + & - \\
\hline & & Attagenus sp. & + & - \\
\hline & Elateridae & Agriotes insanus, Candeze & + & + \\
\hline & & Agrypnus rectangularis, Say & + & - \\
\hline & Scarabaeidae & Digitonthophagus gazella, Fabricius & + & - \\
\hline & & Onthophagus sp. 1 & + & + \\
\hline & & Onthophagus sp.2 & + & - \\
\hline & & Diplotaxis sp. & + & + \\
\hline & & Serica sp. & + & - \\
\hline & Passalidae & Odontotaenius disjunctus, Illiger & + & - \\
\hline & Tenebrionidae & Megeleates sequoiarum, Casey & + & + \\
\hline & & Mordellina sp. & + & - \\
\hline & Curculionidae & Sitophilus oryzae, Linnaeus & - & + \\
\hline & & Dyslobus sp. & + & + \\
\hline & Cleridae & Necrobia rufipes, De Geer & + & + \\
\hline & & Necrobia sp. & + & - \\
\hline \multirow[t]{10}{*}{ Hymenoptera } & Formicidae & Camponotus sp.1 & + & + \\
\hline & & Camponotus sp.2 & + & + \\
\hline & & Camponotus sp.3 & + & + \\
\hline & & Leptogenys sp.1 & + & + \\
\hline & & Leptogenys sp.2 & + & - \\
\hline & & Leptogenys sp.3 & + & - \\
\hline & & Phachycondyla sp. & + & + \\
\hline & & Anoplolepis sp. & + & + \\
\hline & & Tetramorium sp. & + & - \\
\hline & Mutillidae & Unidentified & + & + \\
\hline
\end{tabular}


Zodinpuii, B. et al. / J. Appl. \& Nat. Sci. 11(3): 601- 611 (2019)

Table 4. Species composition of soil arthropods (Centipedes) in Mizoram, northeast India.

\begin{tabular}{lllll}
\hline \multirow{2}{*}{ Class/ Order } & \multirow{2}{*}{ Family } & Taxa & \multicolumn{2}{c}{ Occurrence } \\
\cline { 3 - 5 } & & CTRL & EXPTL \\
\hline Chilopoda Geophilomorpha & Mecistocephalidae & Mecistocephalus guildingii, Newport & + & + \\
& Geophilidae & Geophilus carpophagus, Leach & + & + \\
& & Geophilus insculptus, Attems & + & + \\
Scolopendromorpha & & Geophilus electricus, Linnaeus & + & + \\
\hline
\end{tabular}

$+=$ present, - = absent

Table 5. Species composition of soil arthropods (Millipedes) in Mizoram, northeast India.

\begin{tabular}{lllcr}
\hline \multirow{2}{*}{ Class/ Order } & Family & Taxa & \multicolumn{2}{c}{ Occurrence } \\
\cline { 3 - 5 } & & CTRL & EXPTL \\
\hline Diplopoda Spirostreptida & Spirostreptidae & Spirostreptus sp. & + & + \\
Polydesmida & Cambalopsidae & Glyphiulus sp. & + & - \\
& Paradoxosomatidae & Orthomorpha sp. & + & - \\
& & Oxidus sp. & + & + \\
Sphaerotheriida & Dalodesmidae & Asphalidesmus sp. & + & + \\
\hline
\end{tabular}

$+=$ present, $-=$ absent

Table 6. Order/ Class level's Shannon diversity indices in CTRL and EXPTL sites. Values within the same taxon with different descriptors differ significantly $(p<0.05)$.

\begin{tabular}{|c|c|c|c|}
\hline \multirow{2}{*}{ Taxa } & \multicolumn{2}{|c|}{ Shannon diversity index $(\overline{\mathrm{H}})$} & \multirow{2}{*}{ Diversity t-test } \\
\hline & CTRL & EXPTL & \\
\hline Araneae & $1.792 \mathrm{a}$ & $1.468 \mathrm{~b}$ & $t=2.2722, p=0.0254$ \\
\hline Opiliones & 1.369 & 0.693 & $t=1.976, p=0.15026$ \\
\hline Isopoda & $1.208 \mathrm{a}$ & $0.682 \mathrm{~b}$ & $t=2.8524, p=0.0086$ \\
\hline Blattaria & $1.466 \mathrm{a}$ & $0.682 \mathrm{~b}$ & $t=4.2997, p=0.0002$ \\
\hline Isoptera & 0.828 a & $0.000 \mathrm{~b}$ & $t=29.249, p<0.0001$ \\
\hline Dermaptera & 0.829 & 0.603 & $t=1.4465, p=0.1549$ \\
\hline Orthoptera & $1.011 \mathrm{a}$ & $0.000 \mathrm{~b}$ & $t=3.6502, p=0.0107$ \\
\hline Hemiptera & $0.562 \mathrm{a}$ & $1.560 \mathrm{~b}$ & $t=-2.881, p=0.010$ \\
\hline Coleoptera & $3.385 \mathrm{a}$ & $2.907 \mathrm{~b}$ & $t=3.3403, p=0.0001$ \\
\hline Hymenoptera & $2.221 \mathrm{a}$ & $1.881 \mathrm{~b}$ & $t=21.614, p<0.0001$ \\
\hline Chilopoda & 1.360 & 1.460 & $t=-0.8349, p=0.4073$ \\
\hline Diplopoda & $1.552 \mathrm{a}$ & $0.885 b$ & $t=5.499, p<0.0001$ \\
\hline
\end{tabular}

Table 7. Various indices of CTRL and EXPTL sites in different cultivation phases (2013-2015).

\begin{tabular}{lcccccc}
\hline Index & \multicolumn{2}{c}{ Pre- Cultivation } & \multicolumn{2}{c}{ Cultivation } & \multicolumn{2}{c}{ Post- Cultivation } \\
\cline { 2 - 7 } & CTRL & EXPTL & CTRL & EXPTL & CTRL & EXPTL \\
\hline Taxa (S) & 14 & 12 & 12 & 11 & 16 & 15 \\
Dominance (D) & 0.3623 & 0.3903 & 0.4459 & 0.7534 & 0.3822 & 0.5285 \\
Shannon (H) & 1.373 & 1.364 & 1.09 & 0.667 & 1.425 & 1.148 \\
Simpson (1-D) & 0.6377 & 0.6097 & 0.5541 & 0.2466 & 0.6178 & 0.4715 \\
Evenness & 0.282 & 0.3259 & 0.2477 & 0.1771 & 0.2599 & 0.2102 \\
Menhinick & 0.5833 & 0.6023 & 0.5044 & 0.6278 & 0.5685 & 0.5843 \\
Margalef & 2.045 & 1.838 & 1.735 & 1.746 & 2.247 & 2.157 \\
Equitability (J) & 0.5204 & 0.5488 & 0.4385 & 0.2781 & 0.5141 & 0.424 \\
Fisher alpha & 2.588 & 2.334 & 2.152 & 2.23 & 2.84 & 2.732 \\
Berger- Parker & 0.4844 & 0.5743 & 0.5883 & 0.8664 & 0.5644 & 0.7147 \\
\hline
\end{tabular}

sity of soil macroarthropods at the $p<.05$ level for the three cultivation phases $\left[F_{(2,31)}=5.513, p\right.$ $=.009]$ in EXPTL site.

\section{DISCUSSION}

Soil invertebrates are enormously diverse and may represent as much as $23 \%$ of the total diversity of living organisms that have been described to date (Decaëns et al., 2006). The biological diversity in soils is several orders of magnitude higher than above ground (Heywood and Watson, 1995). However, due to the absolute diversity of soil-living organisms, soil biodiversity studies pose many difficulties in sampling, identification, and interpretation of results. According to Whitford (1992), there are no examples where the soil biota of a specific area of land has been completely described at the species level. Identifying soil invertebrate is a difficult task and required laboratory expertise. Therefore, in order to avoid misidentification, the identification of arthropods is done 
mainly up to family level.

This study recorded 97 taxa of soil macroarthropods during three years of investigation at shifting cultivation site, Khawrihnim, which is quite high. Blower and Wallwork (1971) explained that the phylum Arthropoda was a group of soil animals, which generally showed the highest dominance among the organisms making up the community of soil animals. Brévault et al. (2007) also found that Arthropods were predominant in the invertebrate community in soils under conventional tillage and no-tillage systems.

Scorpiones and Pseudoscorpiones were observed in low numbers which are in accordance with Collins (1980) who stated that Pseudoscorpiones were generally uncommon and Opiliones were erratic in distribution. The higher diversity index of arachnids in forest site as compared to cultivation field may be attributed to the absence of habitat disturbance. Whereas in the cultivation field, regular land management due to slashing, burning and weeding practice was carried out to cause regular soil disturbance. In line with our observation, LoMan-Hung et al. (2011) pointed out that spider species richness and density decreased with regular disturbance and/or high levels of grazing. Several studies predicted that spider density and diversity would be disproportionally impacted by a reduction in plant species richness and habitat complexity (Jeanneret et al., 2003; Perner and Malt, 2003; Haddad et al., 2009). However, Jeanneret et al. (2003) suggested that the most important local habitat factors are those directly influenced by management practices.

It is well known that spiders can exhibit short reaction times to changes in land use (Jeanneret et al., 2003; Perner and Malt, 2003) and subsequently to changes in microclimate (Nyffeler and Sunderland, 2003; Perner and Malt, 2003), soilmoisture (Perner and Malt, 2003), litter cover, litter depth and twig cover (Oxbrough et al., 2005). Since the establishment of crops, pastures and plantations make a significant impact on soil properties, it is expected that the soil spiders would be more significantly affected than what was observed. In fact, most similar studies showed that spider species richness decreased due to soil management intensity (Downie et al., 1999; Perner and Malt, 2003). Furthermore, the increase in spider diversity in disturbed areas is often constrained, even when natural abiotic conditions seem to be restored (Lo-Man-Hung et al., 2008).

Remarkably, both Isopoda and Amphipoda were not recorded from the cultivation field during cultivation phase (2014) while they were recorded from both uncultivated and cultivated sites during Pre- cultivation (2013) and Post- cultivation (2015) phases (Table 7). The disappearance of these two groups during the cultivation phase could be attributed to soil surface disturbance due to burning and weeding practice. This kind of adverse effect of the land use system on snails has been reported by Jordan et al. (2015). This result paralleled the previous studies showing agriculture as the main threat to soil macrofauna communities including macroarthropods like chilopods, diplopods and insects (Muchane et al., 2012). Manetti et al. (2010) found that Crustacea had a higher activity under no-tillage than conventional tillage, consistent with previous results (Wolters and Ekschmitt, 1997; Holland, 2004; Errouissi et al., 2011). According to Wolters and Ekschmitt (1997), isopods are the taxa most affected by tillage practices due to the fact that they are the most sensitive to drought.

This study demonstrated that insects were diverse and observed high in numbers. This was in accordance with the revelation of Borror et al. (1989) in America and Brévault et al. (2007) in Cotton cropping systems of Cameroon, who observed that the Insecta class was the most numerous and diverse class within phylum arthropoda.

Diplurans were too small to be accurately sampled by the present methods; therefore, only largesized diplurans were collected for this study. Family Japygidae was the only species recorded during the study indicating its abundance or it may also be attributed to its versatility. This is in line with Collins (1980) who found $85 \%$ of Japygidae out of all Diplura found on the West Ridge of Gunung (Mount) Mulu, Sarawak.

The diversity index of Isopterans was significantly higher (Table 6) in CTRL as compared to EXPTL site. Black and Okwakol (1997) stated that farming practices can have a profound effect on termite diversity and activity and these changes can be linked to changes in ecological processes, in particular, soil nutrient cycling and water conductivity. Agriculture intensification generally results in a loss of soil biodiversity (Hawksworth, 1991; Swift and Anderson, 1994). Moreover, Ayuke et al. (2009) also observed decreased termite diversity with land use intensification.

Order Coleoptera was observed to be the largest order in terms of diversity. In line with our result, Brown et al., (2001) reported a large number of beetles especially scarab beetles and their larvae (white grubs) in native Brazilian forests and grasslands as well as in agricultural land.

Hymenoptera (ants) were the most dominant $(61.39 \%)$ group of macrofauna in terms of abundance, which is similar to the work of Frouz and Ali (2004) where Formicidae were the dominant soil macroarthropods found in Florida upland habitats. This could be due to their habitual nature of constant burrowing in the soil strata which improves soil fertility by aeration at the surface of the soil. Moreover, Gonçalves et al. (2012) found that Hymenoptera was the most representative group followed by Coleoptera, while centipedes and ear- 
wig were recorded low in number in the Olive grove ecosystem. Mwansat et al. (2012) found that the most dominant group of soil macroarthropod were Hymenoptera $(61.88 \%)$, followed by Coleoptera $(22.32 \%)$, Diploda $(3.26 \%)$ and Homoptera $(2.35 \%)$ in a study conducted in irrigated vegetable plots in Nigeria. This result is also similar to the previous work presented by Liao et al. (2002) where Hymenopterans and Coleopterans were dominant in the tropical rainforest of China. Higher coleopterans abundance, particularly in the natural forest as obtained from this study is consistent with that of Okwakol (2000), who reported that, natural forest was found to be richer than the agroecosystems and that forest clearance and subsequent cultivations resulted in drastic reduction of the number of species compared to the original diversity in forest soils. In most cases, forest disturbance, clearance and cultivation creates a harsh environment intolerable to a number of soil organisms. Meanwhile, Collembolans and Hemipterans have a higher diversity index in cultivation field as compared to natural forest. This higher diversity in cultivation field may be attributed to the fact that cultivation also often enhanced the diversity of some organisms, which is in favor of a theory predicting that increasing disturbance can increase diversity up to a point (Connell, 1978). This is also in line with the results of earlier studies indicating that tillage can either enhance or reduce the diversity of soil macrofauna depending on its intensity and frequency (Wardle, 1999). Allowing greater biomass of weeds by hand-hoed or modifying weed community structure also sometimes enhanced the diversity of some macrofauna. Collembolans depend on freshly decomposed plant litter for food and are mostly available in litter layers. However, only large-sized collembolans were sampled during the study period. This could be the reason for its presence only in cultivation field where the local weeding practice brings about a favourable habitat.

No statistically significant differences in chilopod diversity were observed between CTRL and EXPTL sites (Table 6). Lower diversity of chilopods in the natural forest may be attributed to the occurrence of Scolopendra sp. in cultivation site while there was no record in the natural forest. The freshly semi-tilled soil in the cultivation site may be a favourable habitat for this particular species. Diplopod diversity index was significantly higher in the natural forest as compared to the cultivation site (Table 6 ). This may be attributed to habitat disturbance in the cultivation field by way of clearing weeds and litters. Bogyó et al. (2015) also observed higher diversity and abundance of diplopods in forest edge than adjacent grassland in northeast Hungary.

Effects of cultivation on soil arthropods: The diversity of soil arthropods is still largely unknown in Mizoram and the effect of traditional shifting cultivation on soil arthropods is not widely known either. Shannon's diversity index analysis showed that soil arthropod diversity was significantly $(t=$ 3.443, $p=0.001)$ higher in forest soil, CTRL $(\overline{\mathrm{H}}=$ 1.058) than that of cultivation field, EXPTL $(\overline{\mathrm{H}}=$ 0.753 ). Our results corroborate the findings of Ayuke et al. (2009) revealing that plantation forest in Kenya had higher macroarthropod diversity than agroecosystems. In addition, annual cropping systems decrease the diversity and abundance of soil organisms due to soil disturbance and the absence of a permanent soil cover (Barros et al., 2002). These observed variations in macroarthropod diversity appear to be associated with management practices such as the use of fire and hand hoe, consequent destruction of habitats, modification of soil microclimate within these habitats and removal of substrate, low diversity, and availability of food sources for the associated macrofauna groups.

Many authors (Dangerfield, 1993; Roper and Gupta, 1995; Brown et al., 1996) have shown that management practices such as mechanized land clearing and burning, continuous tillage, monoculture, crop rotation, organic residue inputs, retention and removal and use of agrochemicals were among the causes of the alterations of soil organism's population structure, disappearance or reduction of key species and in some cases extremely low abundances or biomass.

The observations from this study clearly illustrated that soil arthropods were sensitive to cultivation practices. Forest ecosystem had significantly ( $p$ $>.001$ ) higher diversity than that of cultivation site. The result of highest diversity in the natural forest was also reported by Silva et al. (2006) in a study in the Cerrado region, South America, indicating that native forest, where low anthropogenic activity favours the occurrence, more diversified and stable ecosystem of soil organisms.

The results of this study also agreed with other studies that have shown that land use can exert a strong influence on the overall abundance, diversity and community composition of soil organisms (Barrios et al., 2005) as well as soil physical, chemical and biological properties and processes (Six et al., 2004; Barrios, 2007). In line with this study, Ribeiro Filho et al. (2013) stated that soil organism's diversity decreases during the conversion of natural forest to cultivation field, increases during cultivation and recovered during the fallow period. Brown et al. (1996) also observed lower diversity indices in cultivated sites than natural forest sites and associated it to the negative impact of cultivation on the ecosystem functions (comminution, decomposition) mediated by soil organisms. Warren et al. (1987) observed that microclimate, food resources and other land use 
were major factors affecting diversity and abundance of soil organisms. Moreover, many authors (Barros et al., 2002; Rossi et al., 2010; Fonte et al., 2010) agreed that annual cropping systems decrease the diversity and density of soil organisms due to soil disturbance and the absence of a permanent soil cover.

\section{Conclusion}

The observed decrease in species composition and diversity of soil macroarthropods in shifting cultivation site as compared to natural forest in Khawrihnim, Mizoram and the negative impact of shifting cultivation practice on soil arthropods were mainly attributed to habitat disturbances and changed in various physicochemical properties like soil temperature, moisture content, $\mathrm{pH}$, organic carbon, available potassium, available phosphorus and total nitrogen as a result of slashing of trees, burning of dried, felled trees and traditional weeding practices. Therefore, it was concluded from this paper that shifting cultivation system negatively affected soil macroarthropod diversity at least for a short duration. The results obtained from this study provided the first baseline data from shifting cultivation site in Mizoram, northeast India and is expected to provide important information for future reference.

\section{ACKNOWLEDGEMENTS}

We express our sincere thanks to Principal, Pachhunga University College, Aizawl, Mizoram for laboratory facilities, and Mr. H. Zahmingthanga, Khawrihnim for lending us his site for experimentation.

\section{REFERENCES}

1. Alfred, J. R. B., Darlong, V. T., Hattar, S. J. S. and Paul, D. (1991). Microarthropods and their conservation in some North-East Indian soil. Advances in management and conservation of soil fauna, Oxford and IBH Publishing Company Private Limited, New Delhi, pp 309-319.

2. Andersen, A. N. and Majer, J. D. (2004). Ants show the way Down Under: invertebrates as bioindicators in land management. Frontiers in Ecology and the Environment, 2(6), 291-298. https:// doi.org/10.1890/1540-9295(2004)002[0292:astwdu] 2.0.co;2

3. Anderson, J. M. and Ingram, J. S. I. (1993). Tropical soil biological and fertility: a handbook of methods. https://doi.org/10.1097/00010694-199404000-00012

4. Arnett, R. H., and Jacques, R. L. (1981). Simon and Schuster's guide to insects. Simon and Schuster.

5. Ayuke, F., Karanja, N., Muya, E., Kibberenge, M., Mungatu, J. and Nyamasyo, G. (2009). Macrofauna diversity and abundance across different land use systems in Embu, Kenya. Tropical and Subtropical Agroecosystems, 11(2), 371-384.

6. Barrios, E. (2007). Soil biota, ecosystem services and land productivity. Ecological economics, 64(2), 269-285. https://doi.org/10.1016/j.ecolecon.20
07.03.004

7. Barrios, E., Cobo, J. G., Rao, I. M., Thomas, R. J., Amézquita, E., Jiménez, J. J. and Rondón, M. A. (2005). Fallow management for soil fertility recovery in tropical Andean agroecosystems in Colombia. Agriculture, ecosystems and environment, 110(1-2), 29-42. https://doi.org/10.1016/j.agee.2005.04.009

8. Barros, E., Pashanasi, B., Constantino, R. and Lavelle, P. (2002). Effects of land-use system on the soil macrofauna in western Brazilian Amazonia. Biology and Fertility of Soils, 35(5), 338-347. https:// doi.org/10.1007/s00374-002-0479-z

9. Bingham, C. T. (1903). The fauna of British India, including Ceylon and Burma. Hymenoptera, Vol. II. Ants and Cuckoo-wasps. Nature 68(1758), 220-220. https://doi.org/10.1038/068220a0

10.Black, H. I. J. and Okwakol, M. J. N. (1997). Agricultural intensification, soil biodiversity and agroecosystem function in the tropics: the role of termites. $A p$ plied soil ecology, 6(1), 37-53. https:// doi.org/10.1016/s0929-1393(96)00153-9

11.Bogyó, D., Magura, T., Simon, E. and Tóthmérész, B. (2015). Millipede (Diplopoda) assemblages alter drastically by urbanisation. Landscape and Urban Planning, 133, 118-126. https://doi.org/10.1016/ j.landurbplan.2014.09.014

12.Borror, D. J., Triplehorn, C. A. and Johnson, N. F. (1992). An introduction to the study of insects.

13.Brévault, T., Bikay, S., Maldès, J. M. and Naudin, K. (2007). Impact of a no-till with mulch soil management strategy on soil macrofauna communities in a cotton cropping system. Soil and Tillage Research, 97(2), 140-149. https://doi.org/10.1016/ j.still.2007.09.006

14.Brown, G. G., Moreno, A. G. and Lavelle, P. (1996). Soil macrofauna under different Agricultural Systems and native vegetation in four countries of East Africa. Biological Management of Soil Fertility in Small-Scale Farming Systems in Tropical Africa, 2nd Annual report.

15.Brown, G. G., Pasini, A., Benito, N. P., De Aquino, A. M. and Correia, M. E. F. (2001). Diversity and functional role of soil macrofauna communities in Brazilian no tillage agroecosystems: A preliminary analysis. International Symposium on Managing biodiversity in agricultural ecosystems, Londrina: Embrapa Soja, pp 8-10.

16.Callaham, M. A., Crossley, D. A. and Coleman, D. C. (2012). Soil Fauna: Macroarthropods. Handbook of Soil Sciences: Properties and Processes (2nd Edition), CRC Press, Boca Raton, pp 19-26.

17. Castner, J. L. (2000). Photographic atlas of entomology and guide to insect identification (No. C/595.7 C3).

18.Collins, N. M. (1980). The distribution of soil macrofauna on the west ridge of Gunung (Mount) Mulu, Sarawak. Oecologia, 44(2), 263-275. https:// doi.org/10.1007/bf0057268

19. Connell, J. H. (1978). Diversity in tropical rain forests and coral reefs. Science, 199(4335), 1302-1310. https://doi.org/10.1126/science.199.4335.1302

20.Dangerfield, M. J. (1993). Soil animals and soil fertility: a critical component of woodland productivity.

21.Darlong, V. T. and Alfred, J. R. B. (1982). Differences in arthropod population structure in soils of forest and Jhum sites of North-East India. Pedobiologia, 23, 112 -219 . 
22.Dash, M. C. and Patra, U. C. (1977). Density, biomass and energy budget of a tropical earthworm population from a grassland site in Orissa, India. Revue d Ecologie Et de Biologie du Sol, 14(3):461471.

23.Dash, M. C. and Senapati, B. K. (1980). Cocoon morphology, hatching and emergence pattern in tropical earthworms. Pedobiologia, 20(5), 316-324.

24.Decaëns, T., Jiménez, J. J., Gioia, C., Measey, G. J. and Lavelle, P. (2006). The values of soil animals for conservation biology. European Journal of Soil Biology, 42, S23-S38.

25.Doğramaci, M. and Tingey, W. M. (2009). Host resistance and influence of tuber surface on larval performance of potato tuberworm (Lepidoptera: Gelechiidae). Journal of pest science, 82(2), 109-114.

26.Downie, I. S., Wilson, W. L., Abernethy, V. J., McCracken, D. I., Foster, G. N., Ribera, I., Murphy K. J. and Waterhouse, A. (1999). The impact of different agricultural land-uses on epigeal spider diversity in Scotland. Journal of insect Conservation, 3(4):273286.

27.Edwards, C. A. and Bohlen, P. J. (1996). Biology and ecology of earthworms (Vol. 3). Springer Science and Business Media.

28.Errouissi, F., Moussa-Machraoui, S. B., BenHammouda, M. and Nouira, S. (2011). Soil invertebrates in durum wheat (Triticum durum L.) cropping system under Mediterranean semi arid conditions: A comparison between conventional and no-tillage management. Soil and Tillage Research, 112(2), 122 -132. https://doi.org/10.1016/j.still.2010.12.004

29.Fonte, S. J., Barrios, E. and Six, J. (2010). Earthworms, soil fertility and aggregate-associated soil organic matter dynamics in the Quesungual agroforestry system. Geoderma, 155(3-4), 320-328. https:// doi.org/10.1016/j.geoderma.2009.12.016

30.Frouz, J. and Ali, A. (2004). Soil macroinvertebrates along a successional gradient in central Florida. The Florida Entomologist 87(3), $386 \quad-390 . \quad$ https:// doi.org/10.1653/0015-4040(2004)087[0386:smaasg] 2.0.co;2

31.Gibb, T. J., Oseto, C. Y. and Oseto, C. (2006). Arthropod collection and identification: laboratory and field techniques. Academic press.

32. Gonçalves, M. F., Pereira, J. A. and Liu, T. X. (2012). Abundance and diversity of soil arthropods in the olive grove ecosystem. Journal of Insect Science 12(1). https://doi.org/10.1673/031.012.2001

33. Haddad, N. M., Crutsinger, G. M., Gross, K., Haarstad, J., Knops, J. M. and Tilman, D. (2009). Plant species loss decreases arthropod diversity and shifts trophic structure. Ecology Letters , 12(10), 10291039. 0248.2009.01356.x

34.Hammer, Ø., Harper, D. A. and Ryan, P. D. (2001). PAST: paleontological statistics software package for education and data analysis. Palaeontologia electronica, 4(1), 9.

35. Hattar, S. J. S. and Alfred, J. R. B. (1984). A population study and community analysis of Collembola in pine forest soils of Meghalaya. NE India-III Oriental Entomology Symposium, pp 203-209.

36. Hattar, S. J. S., Alfred, J. R. B. and Darlong, V. T. (1998). Animal diversity in some managed and protected forests of North-East India with particular reference to soil fauna. Agro Botanica, 11, 108-118.
37.Hattar, S. J. S., Alfred, J. R. B. and Darlong, V. T. (1992). Soil acarina and collembola in forest and cultivated land of Khasi Hills, Meghalaya. Record of Zoological Survey of India, 92, 89-97.

38. Hattar, S. J. S., Darlong, V. T. and Alfred, J. R. B. (2008). Soil fauna diversity and shifting cultivation: an observation from north-east India. Annals of Forest, 16(2), 340-357.

39. Hawksworth, D. L. (1991). The biodiversity of microorganisms and invertebrates: its role in sustainable agriculture. $\mathrm{CAB}$ International.

40. Heywood, V. H. and Watson, R. T. (1995). Global biodiversity assessment (Vol. 1140). Cambridge: Cambridge University Press.

41. Holland, J. M. (2004). The environmental consequences of adopting conservation tillage in Europe: reviewing the evidence. Agriculture, ecosystems and environment, 103(1), 1-25.

42. Hunter, M. D. (2001). Insect population dynamics meets ecosystem ecology: effects of herbivory on soil nutrient dynamics. Agricultural and Forest Entomology, 3(2), 77-84. https://doi.org/10.1046/j.14619563.2001.00100.x

43. Imms, A. D. (1912). On some Collembola from India, Burma, and Ceylon; with a Catalogue of the Oriental Species of the Order. Proceedings of the Zoological Society of London, Oxford, UK, Blackwell Publishing Ltd, pp 80-125.

44.Jackson, T. A. and Klein, M. G. (2006). Scarabs as pests: a continuing problem. The Coleopterists Bulletin, 60(mo5), 102-119.

45.Jeanneret, P., Schüpbach, B., Pfiffner, L. and Walter, T. (2003). Arthropod reaction to landscape and habitat features in agricultural landscapes. Landscape ecology, 18(3), 253-263.

46. Lavelle, P. (1997). Faunal activities and soil processes: adaptive strategies that determine ecosystem function. Advances in ecological research, Academic Press, pp 93-132. https://doi.org/10.1016/s0065-2504 (08)60007-0

47.Liao, C., Li, J., Yang, Y. and Zhang, Z. (2002). The Community of Soil Animal in Tropical Rain Forest in Jianfengling Mountain, Hainan Island, China Composition and Characteristics of Community. Acta Ecologica Sinica, 22(11), 1866-1872.

48.Lo-Man-Hung, N. F., Gardner, T. A., Ribeiro-Júnior, M. A., Barlow, J. and Bonaldo, A. B. (2008). The value of primary, secondary, and plantation forests for Neotropical epigeic arachnids. The Journal of Arachnology, 36(2), $394-402$.

49.Lo-Man-Hung, N. F., Marichal, R., Candiani, D. F., Carvalho, L. S., Indicatti, R. P., Bonaldo, A. B., Cobo, D. H., Feijoo, A. M., Tselouiko, S., Praxedes, C. and Brown, G. (2011). Impact of different land management on soil spiders (Arachnida: Araneae) in two Amazonian areas of Brazil and Colombia. The Journal of Arachnology , 39(2), $296-303 . \quad$ https:// doi.org/10.1636/cp10-89.1

50.Manetti, P. L., López, A. N., Clemente, N. L. and Faberi, A. J. (2010). Tillage system does not affect soil macrofauna in southeastern Buenos Aires province, Argentina. Spanish Journal of Agricultural Research, 8(2), 377-384. https://doi.org/10.5424/ sjar/2010082-1189

51.Muchane, M. N., Karanja, D., Wambugu, G. M., Mutahi, J. M., Clet, W., Mugoya, C, and Muchai, M. (2012). Land use practices and their implications on 
soil macro-fauna in Maasai Mara ecosystem. International Journal of Biodiversity and Conservation, 4 (13), 500-514.

52.Mwansat, G. S., Njila, H. L. and Levi, R. Y. (2012). A Study of Species Diversity and Distribution of Soil Macroarthropod Fauna in Irrigated Vegetable Plots in Jos South Local Government Area, Plateau State, Nigeria.

53.Nakamura, A., Catterall, C. P., House, A. P., Kitching, R. L. and Burwell, C. J. (2007). The use of ants and other soil and litter arthropods as bio-indicators of the impacts of rainforest clearing and subsequent land use. Journal of Insect Conservation, 11(2), 177186. https://doi.org/10.1007/s10841-006-9034-9

54.Nyffeler, M. and Sunderland, K. D. (2003). Composition, abundance and pest control potential of spider communities in agroecosystems: a comparison of European and US studies. Agriculture, Ecosystems and Environment, 95(2-3), 579-612. https:// doi.org/10.1016/s0167-8809(02)00181-0

55.Okwakol, M. J. (2000). Changes in termite (Isoptera) communities due to the clearance and cultivation of tropical forest in Uganda. African Journal of Ecology, 38(1), 1-7. https://doi.org/10.1046/j.13652028.2000.00189.x

56.Okwakol, M. J. N. and Sekamatte, M. B. (2007). Soil macrofauna research in ecosystems in Uganda. African Journal of Ecology , 45, 2-8. https:// doi.org/10.1111/j.0141-6707.2007.00800.x

57.Oxbrough, A. G., Gittings, T., O'Halloran, J., Giller, P. S. and Smith, G. F. (2005). Structural indicators of spider communities across the forest plantation cycle. Forest Ecology and management, 212(1-3), 171183. https://doi.org/10.1016/j.foreco.2005.03.040

58.Paul, D. and Alfred, J. R. B. (1995). Soil arthropod fauna of three agroecosystems as compared to that of undisturbed forests of Meghalaya, NE India. Journal of Soil Biology and Ecology, 15, 52-65.

59.Perner, J. and Malt, S. (2003). Assessment of changing agricultural land use: response of vegetation, ground-dwelling spiders and beetles to the conversion of arable land into grassland. Agriculture, Ecosystems and Environment, 98(1-3), 169-181. https://doi.org/10.1016/s0167-8809(03)00079-3

60.Pocock, R. I. (1892). XXXVIII._Liphistius and its bearing upon the classification of spiders. Journal of Natural History, 10(58), 306-314. https:// doi.org/10.1080/00222939208677416

61.Reddy, M. V. and Alfred, J. R. B. (1978). Some observations on the earthworm population and the biomass in a sub-tropical pine forest soil. Soil Biology and Ecology in India, UAS Technical Series, Bangalore, pp 78-82.

62.Ribeiro Filho, A. A., Adams, C. and Murrieta, R. S. S. (2013). The impacts of shifting cultivation on tropical forest soil: a review. Boletim do Museu Paraense Emílio Goeldi. Ciências Humanas, 8(3), 693-727. https://doi.org/10.1590/s1981-81222013000300013

63.Roper, M. M. and Gupta, V. V. S. R. (1995). Management-practices and soil biota. Soil Research, 33 (2), 321-339. https://doi.org/10.1071/sr9950321

64.Rossi, J. P. and Blanchart, E. (2005). Seasonal and land-use induced variations of soil macrofauna composition in the Western Ghats, southern India. Soil biology and biochemistry, 37(6), 1093-1104. https:// doi.org/10.1016/j.soilbio.2004.11.008

65.Rossi, J. P., Celini, L., Mora, P., Mathieu, J., Lapied,
E., Nahmani, J., Ponge, J. F. and Lavelle, P. (2010). Decreasing fallow duration in tropical slash-and-burn agriculture alters soil macroinvertebrate diversity: a case study in southern French Guiana. Agriculture, ecosystems and environment, 135(1-2), 148-154. https://doi.org/10.1016/j.agee.2009.08.012

66.Ruiz, N., Lavelle, P. and Jimenez, J. (2008). Soil macrofauna field manual.Food and Agriculture Organization, Rome, Italy. pp 1-113.

67.Silva, J. F., Farinas, M. R., Felfili, J. M. and Klink, C. A. (2006). Spatial heterogeneity, land use and conservation in the cerrado region of Brazil. Journal of Biogeography, 33(3): 536-548.

68.Singh, J. (1978). Soil fauna studies in India. In C.A. Edwards and G.K. Veeresh (Eds.), Soil Biology and Ecology in India, University of Agricultural Sciences, Technical Series No. 22, Bangalore. pp. 226-235.

69.Six, J., Bossuyt, H., Degryze, S. and Denef, K. (2004). A history of research on the link between (micro) aggregates, soil biota, and soil organic matter dynamics. Soil and Tillage Research, 79(1), 7-31. https://doi.org/10.1016/j.still.2004.03.008

70.Swift, M. J. and Anderson, J. M. (1994). Biodiversity and ecosystem function in agricultural systems. In Biodiversity and ecosystem function, Springer, Berlin, Heidelberg, pp. 15-41. https://doi.org/10.1007/978-3642-58001-7_2

71.Swift, M. and Bignell, D. (2001). Standard methods for assessment of soil biodiversity and land use practice, Bogor, Indonesia: International Centre for Research in Agroforestry, pp 3-34.

72.Jordan Tolley, L., Huryn, A. D. and Bogan, A. E. (2015). Effects of land-use change on a diverse pleurocerid snail assemblage. Aquatic Conservation: Marine and Freshwater Ecosystems, 25(2), 235-249. https://doi.org/10.1002/aqc.2474

73.Vatsauliya, P. K. (1981). Ecological studies on Jhum fallows of Byrnihat Meghalaya with particular reference to soil fauna.

74.Vatsauliya, P. K. and Alfred, J. R. B. (1980). Quantitative study of the soil arthropods in Jhum ecosystems of northeast India. Indian Zoologist, 4, 153-160.

75.Blower J.G. and Wallwork, J. A. (1971). Ecology of soil animals. Journal of Animal Ecology 40(2):541 DOI: $10.2307 / 3269$

76.Wardle, D. A., Nicholson, K. S., Bonner, K. I., \& Yeates, G. W. (1999). Effects of agricultural intensification on soil-associated arthropod population dynamics, community structure, diversity and temporal variability over a seven-year period. Soil Biology and Biochemistry, 31(12), 1691-1706. https:// doi.org/10.1016/s0038-0717(99)00089-9

77.Warren, S. D., Scifres, C. J. and Teel, P. D. (1987). Response of grassland arthropods to burning: a review. Agriculture, ecosystems and environment, 19 (2): 105-130. https://doi.org/10.1016/0167-8809(87) 90012-0

78.Whitford, W. G. (1992). Effects of climate change on soil biotic communities and soil processes. Global warming and biological diversity, pp 124-136.

79.Wolters, V. (2000). Invertebrate control of soil organic matter stability. Biology and fertility of Soils, 31(1), 1-19. https://doi.org/10.1007/s003740050618

80.Wolters, V. and Ekschmitt, K. (1997). Gastropods, isopods, diplopods, and chilopods: neglected groups of the decomposer food web. Fauna in soil ecosystems, CRC Press, pp 279-320. 